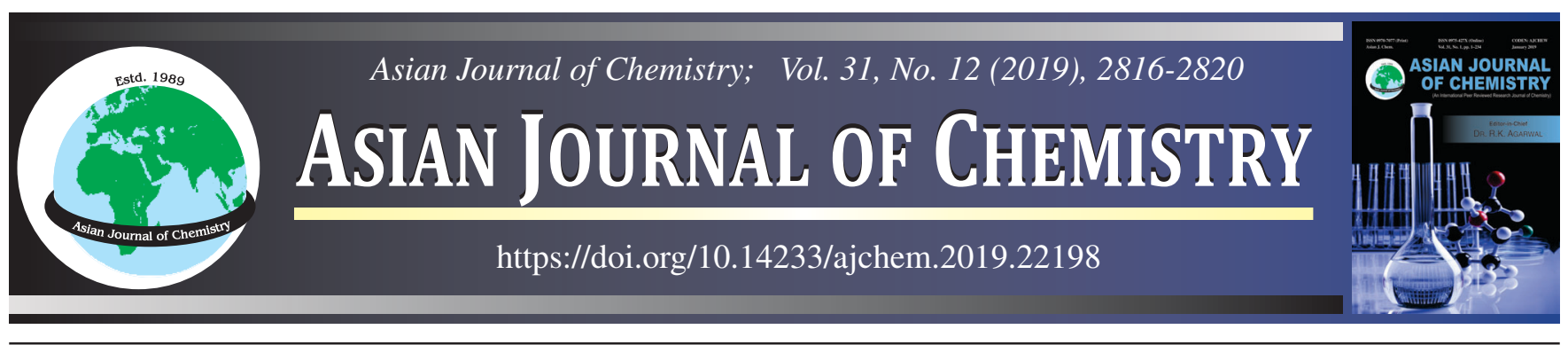

\title{
Improvement of Methane Yield by Anaerobic Co-Digestion of Sewage and Petrochemical Wastewater: Effect of Temperature
}

\author{
M.N.I. SidDiQuE* and M.F. AHMAD
}

School of Ocean Engineering, Universiti Malaysia Terengganu, 21030 Kuala Nerus, Terengganu, Malaysia

*Corresponding author: Fax: +60 9 5493006, Tel: +60 9 6683614; E-mail: m.nurul@umt.edu.my

Anaerobic bio-digestibility of blend municipal sewage sludge (MSS), condensed waste activated sludge (CWAS) and petrochemical wastewater (PWW) has been evaluated utilizing semi-continuous operation, anaerobic reactors worked during mesophilic $\left(37^{\circ} \mathrm{C}\right)$ and thermophilic $\left(55^{\circ} \mathrm{C}\right)$ states. Supplementation of a significant PWW portion (49\% of VS) in an MSS + CWAS combination brought about 2.94 times more methane production, 153 versus $450 \mathrm{~mL} / \mathrm{g}$ volatile solids (VS) under $37^{\circ} \mathrm{C}$ furthermore 2.59 times more methane production, 198 versus $513 \mathrm{~mL} / \mathrm{g}$ VS under $55^{\circ} \mathrm{C}$. The supplemented PWW portion might have been not inhibitory for the system. Those effects of this work show the profit from municipal sewage sludge, condensed waste activated sludge and petrochemical wastewater co-digestion.

Keywords: Anaerobic co-digestion, Municipal sewage sludge, Condensed waste activated sludge, Petrochemical wastewater.

\section{INTRODUCTION}

Refineries are noteworthy suppliers of petrochemical wastewater which truly made an extreme environmental pollutions $[1,2]$ studied a half expands in methane generation by codigestion system and minimizing about $0.49 \mathrm{~kg} \mathrm{VS} / \mathrm{m}^{3}$-d petrochemical wastewater. The possibility of enhanced methane generation by hundred percent through the co-digestion of condensed waste activated sludge (CWAS) and municipal sewage sludge (MSS) was showed over lab investigations [3].

For enhanced biogas generation and to provide sustainable reuse of petrochemical wastewater (PWW) and municipal sewage sludge (MSS), Terengganu province of Malaysia need to run anaerobic co-digestion plants and discharge facility of the effluent. Petrochemical wastewater (PWW) is particularly intriguing as it yields more noteworthy methane creation which can without much of a stretch blend with sewage sludge. Be that as it may, PWW have a few inconveniences: there might be insufficient lipids for gaining admittance to microorganisms and unsaturated fats likewise make them frustrate properties. Kaborious et al. [4] thought about the ACoD of primer and profluent slop with fats, oil and grease (FOG) gathered from wastewater treatment plant (WTP) [4]; foreseen anaerobic codigestion of glycerol with sewage sludge [5]. Davidsson et al. [6] investigated anaerobic co-digestion of sewage sludge with ooze originating from oil trap [7]. In reality, semi-ceaselessly worked anaerobic co-digestion remained is conceivable by including slop of oil trap about 10-30\% or $46 \%$ natural feed, yet unreasonably over the top $71 \%$ volatile solids (VS) and $55 \%$ lipid content in the feed mix realized insufficient absorption and the digester fermentation with a succeeding decrease in creating biogas [8]. The obstacle in the methanogenesis stage by unsaturated fats having long-chain has been incited by over-loading.

To our best of knowledge, the co-digestion of municipal sewage sludge (MSS), condensed waste activated sludge (CWAS) and petrochemical wastewater (PWW) has not been studied till to date. The aim of this work might have been on survey furthermore quantify those anaerobic biodegradations about MSS co-digested with huge amounts for PWW, under totally blended semi-continuously nourished mesophilic alternately thermophilic methane production. Such data will be beneficial to securing that possibility furthermore reduces expense of that co-digestion for MSS and PWW. Benchmark information utilized in this work included extreme degradability for those

This is an open access journal, and articles are distributed under the terms of the Attribution 4.0 International (CC BY 4.0) License. This license lets others distribute, remix, tweak, and build upon your work, even commercially, as long as they credit the author for the original creation. You must give appropriate credit, provide a link to the license, and indicate if changes were made. 
sewage and FOG (fats, oil and grease) segments, alongside mesophilic and thermophilic semi-continuous co-digestion for without municipal sewage sludge (MSS) and petrochemical wastewater (PWW) [4].

\section{EXPERIMENTAL}

Test accumulation: The petrochemical wastewater (PWW) was collected from petronas penapisan Terengganu, Malaysia and municipal sewage sludge (MSS) was taken from Bukit Losong 1 Water Treatment Plant, Kuala Terengganu, Terengganu, Malaysia. Those MSS and PWW samples were dispatched to laboratory immediately and preserved at $4{ }^{\circ} \mathrm{C}$. As municipal sewage sludge (MSS) samples were diluted (1.3\% TS, $0.8 \%$ VS), therefore, MSS have been preserved at $4{ }^{\circ} \mathrm{C}$ to 2 days and the resilient have been thickened.

Batch tests: A batch test has been performed with those municipal sewage sludge (MSS), condensed waste activated sludge (CWAS) and petrochemical wastewater (PWW) separately, and additionally in mixture (MSS + CWAS; MSS + CWAS + PWW) utilizing $150 \mathrm{~mL}$ serum flasks. Seeds have been cultivated from Losong 1 water treatment plant, Kuala Terengganu, Terengganu, Malaysia mesophilic anaerobic digesters, which have been pre-digested for 90 days [9]. Incubation have been carried out in the $\operatorname{dim} \operatorname{In} 37^{\circ} \mathrm{C}$ and the bottles were shaken manually one time per day.

Fermentation framework: The whole assimilation framework incorporated two automatically blended $5 \mathrm{~L}$ and $1.5 \mathrm{~L}$ glass digesters. Each reactor required a water coat furthermore their heats have been maintained by a water recirculation system utilizing two warmed water baths. The $5 \mathrm{~L}$ digester has been set on $37{ }^{\circ} \mathrm{C}$ and the different $5 \mathrm{~L}$ reactor has been set on 57 ${ }^{\circ} \mathrm{C}$. The $1.5 \mathrm{~L}$ digester used as the feeding tank, have been set to room temperature $\left(22-24^{\circ} \mathrm{C}\right)$, also have been cleaned once a day. Both digesters were squandered manually one time per day using syringe, 5 min prior to running. Feeding of both digesters have been attained manually once a day by a $50 \mathrm{~mL}$ syringe (operation 1), alternately with a peristaltic pump for 6 min each $4 \mathrm{~h}$ (operation 2). Gas specimens were collected from those digesters by syringe and examined.

Digester start-up: The mesophilic digester has been operated with a processed sewage example acquired from Bukit Losong 1 water treatment plant, Kuala Terengganu, Terengganu, Malaysia. The thermophilic digester might have been off taking after the same system. Both digesters were equilibrated to the required temperature of 5 days before operation. The primary $\mathrm{pH}$ for both digesters was 7. 5 and 7.7.

Fermentation: Non-stop testing for municipal sewage sludge (MSS), condensed waste activated sludge (CWAS) and petrochemical wastewater (PWW) under both mesophilic and thermophilic states has been directed in two runs. Operation 1 involved a regulate examination about mesophilic versus thermophilic fermentation and the feed have been a blend for MSS and CWAS. For operation 2, the feed has been a blend of MSS, CWAS and PWW and has been operated on two sideby-side methane stage reactors running individually, during mesophilic and thermophilic states.

Analysis: All the water quality parameters were measured according to standard procedures of APHA, 2005. Biogas generation sum was measured by section moving strategy where at $10 \mathrm{~g} / \mathrm{L}$ of $\mathrm{NaCl}$ and $\mathrm{pH} 2$, the liquid getting to be water. The accuracy of this estimate was $\pm 10 \mathrm{~mL}$ for semi-persistent reactors and $\pm 1 \mathrm{~mL}$ for bunch tests. The biogas fraction was analyzed by a gas chromatography device (Shimadzu GC-8A) outfitted with an integrator C-R8A and a connected CTRI segment, which was included two fragments: $3.18 \mathrm{~mm}$ separate over the inside section, stacked by silica gel, permitted separation of carbon dioxide from different gasses. A $6.4 \mathrm{~mm}$ estimation outside segment, stacked with a sub-nuclear strainer, detached option gasses. Argon gas was utilized as the transporter gas at $2.7 \mathrm{bar}$. The stove and injector and indicator temperature were 30 and $105^{\circ} \mathrm{C}$ individually. The vaporous material identification was completed by a warmth sensor and the electric flow thickness was kept $75 \mathrm{~mA}$. The volume of infused biogas was $1.5 \mathrm{~mL}$ (Fig. 1). The institutionalization was performed with a standard gas made of $24 \%$ carbon dioxide, $6 \%$ hydrogen, $2.5 \%$ oxygen, $9.5 \%$ nitrogen and $58 \%$ methane.

The volatile fatty acids (VFA) was estimated by a gas chromatography gadget (Fisons Instruments, GC-8000) which was outfitted by a flame ionization marker and a modified analyzer (Fisons Instruments, AS 800). The segment portion had a length of $14 \mathrm{~m}$, the width of $0.52 \mathrm{~cm}$ and Phase EC 1000 film was $1.3 \mu \mathrm{m}$ named as semi-fine Econocap FFAP (Alltech). The temperature for splitless injector temperature $\left(245^{\circ} \mathrm{C}\right)$ and the indicator $\left(270^{\circ} \mathrm{C}\right)$ were adjusted separately. Within $3 \mathrm{~min}$, the reactor temperature was increased from $85^{\circ} \mathrm{C}$ to $125^{\circ} \mathrm{C}$. At $24 \mathrm{kPa}$, nitrogen was utilized as the transporter gas. The infused test volume was $1 \mu \mathrm{L}$. Hardware institutionalization was set up by a legitimate blending of six kinds of acids: acitic acid, butyric acid, valeric acid, propionic acid, isovaleric acid and isobutyric acid at $1.0 \mathrm{~g} / \mathrm{L}$ exclusively. Scope of institutionalization was kept $0.25-1.0 \mathrm{~g} / \mathrm{L}$ by standard blend weakening. All out VFA level was estimated by center standard procedure (aging of $50 \mathrm{~mL} \mathrm{H}_{3} \mathrm{PO}_{4}, 1.0 \mathrm{~g}$ of ethyl-2-butyric acid was destructive in water of $1.0 \mathrm{~L}$ ) by a blend of equivalent volume of the example and the inner standard arrangement.

\section{RESULTS AND DISCUSSION}

Those outcomes of the analysis of municipal sewage sludge (MSS), condensed waste activated sludge (CWAS) and petrochemical wastewater (PWW) shown that all wastewater samples were acidic with the CWAS had the maximum $\mathrm{pH}$ of 6.7 , those PWW example Hosting the least $\mathrm{pH}$ of 4.1, and the recreated MSS blend had a $\mathrm{pH}$ of 5. 7. Those COD/VS proportion might have been 2.28, 1.95 and 2.97 to that MSS, CWAS and PWW sample. A huge level of dissolvable COD and VFAs might have been found in the samples, demonstrating that a remarkable level of solubilization and pre-acidification took place during shipping. All specimens had higher ammonia concentration over $200 \mathrm{mg} / \mathrm{L}$. The TKN-to-VS proportion to PWW (0. 013) might have been lower compared with MSS (0.07-0.08). Further subtle elements for characterization are described elsewhere [10].

Biodigestibility: These biodigestibility tests have been done after 120 days and points were stated by Siddique et al. [11]. The measurement of methane generated normalized to the COD removed ranged between 339 to $344 \mathrm{~mL} / \mathrm{g}$ COD, 


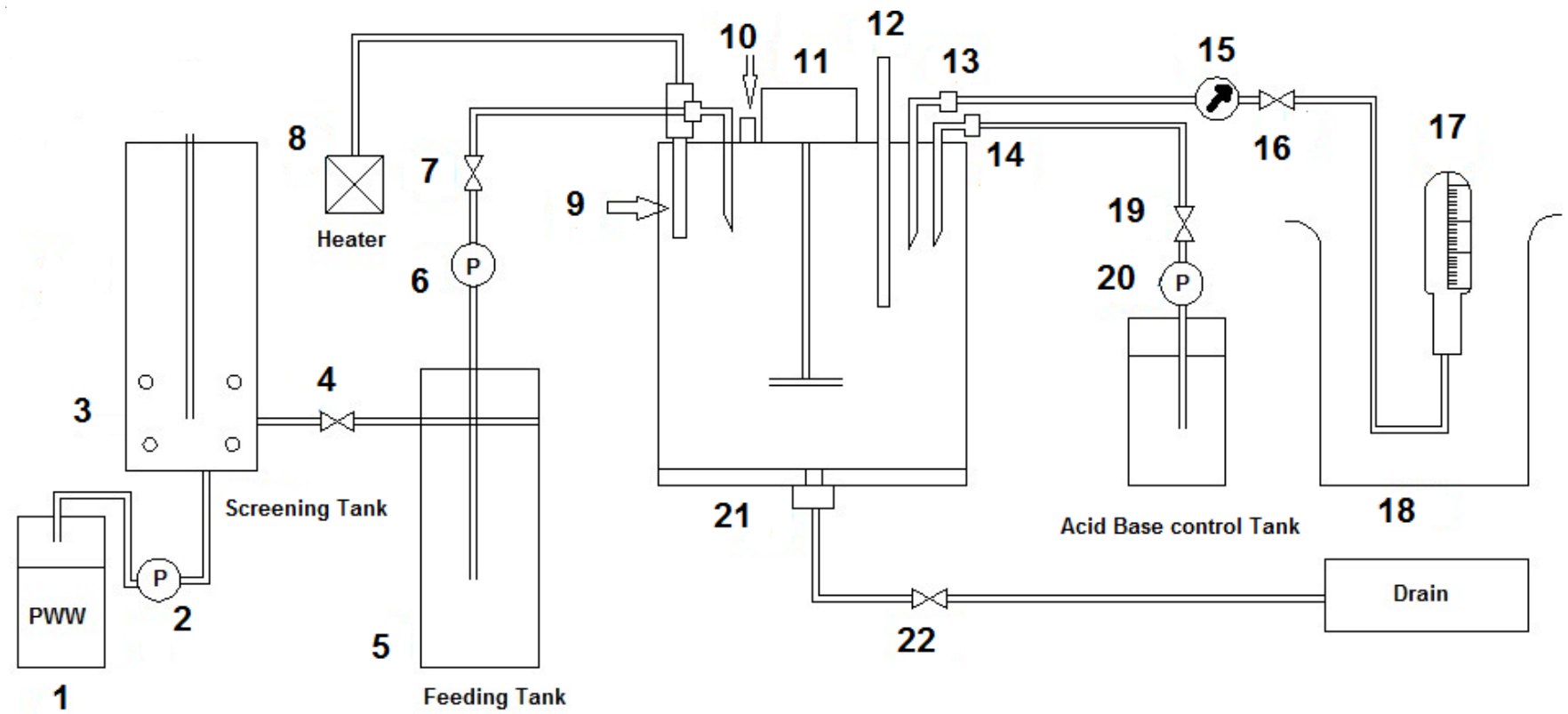

Fig. 1. Experimental setup of CSTR. 1 = Raw PWW dosing zone; 4,7,16,19,22 = Control valve; $3=$ Screening tank, $5=$ Feeding tank; $2,6,20$ $=$ Peristalic pump; $8=$ Heater; $9=$ Temperature sensor; $10=$ Pressure controller; $11=$ Stirrer motor with stirrer; $12=\mathrm{pH}$ sensor; $13=$ Gas collection wire; 14 = Acid base control wire; 15 = Biogas flow meter; 17 = Biogas collection tank; 21 = Process reactor (capacity $5 \mathrm{~L}) ; 18=$ Water displacement system

which will be near to hypothetical value of $349 \mathrm{~mL} \mathrm{~mL} / \mathrm{g}$ COD. That experimental methane yield for every unit volatile solid (VS) impostor supplemented to these specimens might have been 471, 180, 994 and $292 \mathrm{~mL} / \mathrm{g}$ VS added, individually. Siddique et al. [12] studied that those outcomes of a blend of the wastes might a chance to be sensibly estimated by accepting that every individual wastewater potential to volatile solid and COD removals were consistent. Dependent upon those extreme biodegradability outcomes for every part (MSS, CWAS and PWW) and bringing under consideration those volatile solid portion from claiming each part in the MSS21 + CWAS31 + PWW48 combination, which speaks to the encourage blend for operation 2, those anticipated for the blend volatile solid and COD removals were $53 \%$ and $55 \%$, respectively, and the methane yield might have been estimated to be $631 \mathrm{~mL} / \mathrm{g} \mathrm{VS}$.

Operation 1: The operation 1 has been directed to straightforward analyze mesophilic versus thermophilic fermentation of a blend of MSS and CWAS. Points to this operation are reported by Siddique et al. $[9,11,12]$. Both digesters were operated under precisely similar states, but to their temperature ( 37 versus $55^{\circ} \mathrm{C}$ ). Digestion performance of operation 1 is shown in Table-1. The operational loadings for operation 1 were: $42.4 \pm 0.3 \mathrm{~g} \mathrm{TS} / \mathrm{L} ; 30.3 \pm 0.2 \mathrm{~g} \mathrm{VS} / \mathrm{L} ; 54 \pm 3.8 \mathrm{~g} \mathrm{COD} / \mathrm{L}$; $4.9 \pm 0.15 \mathrm{~g} \mathrm{COD} / \mathrm{L} ; 3.5 \pm 0.30 \mathrm{~g}$ VFA-COD/L; $6.50 \pm 0.03$ $\mathrm{pH}$; and $0.3 \pm 0.02 \mathrm{~g}$ ammonia-N/L. Acidification of feed substrates took place which made $\mathrm{pH}$ and VFA levels consistent for the full-scale digesters [13]. The volatile solid removal has been $26.3 \%$ and $31.6 \%$ in the mesophilic and thermophilic digesters, respectively, Furthermore might have been roughly equivalent to the connected cod decimation about $26.4 \%$ and $30.5 \%$. Acknowledging that extreme degradability from volatile solid and COD deposition for 121-day, the thermophilic digester attained volatile solid and COD removal about $84 \%$ and $75 \%$, separately. The corresponding degradable volatile

\begin{tabular}{lcc}
\multicolumn{4}{c}{ TABLE-1 } \\
\multicolumn{3}{c}{ DIGESTER PROPERTIES OF OPERATION 1 } \\
\multicolumn{1}{c}{ Parameters 2} \\
\hline Volume (L) & Operation 1 & Operation 2 \\
HRT (day) & 1.99 & 1.99 \\
Flow rate (mL/day) & 13 & 13 \\
MSS loading g VS/L-day (\%) & 167 & 167 \\
CWAS loading g VS/L-day (\%) & 0.98 & 0.91 \\
PWW loading g VS/L-day (\%) & 1.44 & 1.34 \\
Total loading g VS/L-day & - & 2.1 \\
\hline MSS = Municipal sewage sludge, CWAS = Condensed waste activated \\
sludge, PWW = Petrochemical wastewater.
\end{tabular}

solid and COD removal values for that mesophilic reactor were just $69 \%$ and $64 \%$, separately. Methane yield has been 160 and $198 \mathrm{~mL} / \mathrm{g}$ VS to the mesophilic and thermophilic digester, individually. Final ammonia levels of mesophilic and thermophilic digester were 496 and $720 \mathrm{mg} / \mathrm{L}$, respectively, which relate with a net ammonia generation about 197 and $421 \mathrm{mg} / \mathrm{L}$, respectively, during the feed ammonia had been deducted. This demonstrates that more proteinaceous material might have been digested at thermophilic states.

Operation 2: This operation might have been operated specifically for the comparison of mesophilic versus thermophilic co-digestion of a blend of MSS, CWAS and PWW also to show the enhancement of methane yield because of PWW addition. The digesters aspects throughout operation 2 are recorded in Table-1, while the feeding details of operation 2 are listed in Table- 2 . Those dissolvable COD were $5 \%$ of the total COD and over $80 \%$ of the dissolvable COD might have been comprised of VFAs, which were $5 \mathrm{~g} / \mathrm{L}$. The influent acidification had been occurred that consolidated with the PWW's low $\mathrm{pH}$ quality of around 5.0 brought about a low influent $\mathrm{pH}$ for 5.6. 
TABLE-2

DIGESTER OUTPUT FOR AFTER OPERATION (Average \pm SD)

\begin{tabular}{lccc}
\hline \multicolumn{1}{c}{ Parameters } & Influent & $\begin{array}{c}\text { Effluent } \\
\text { (Meso- } \\
\text { philic) }\end{array}$ & $\begin{array}{c}\text { Effluent } \\
\text { (Thermo- } \\
\text { philic) }\end{array}$ \\
\hline Total solids (g/L) & $63 \pm 0.5$ & $42 \pm 0.3$ & $38 \pm 0.3$ \\
Volatile solids (g/L) & $52 \pm 0.4$ & $28 \pm 0.3$ & $25 \pm 0.3$ \\
Total COD (g/L) & $130 \pm 9$ & $68 \pm 3$ & $58 \pm 2$ \\
Soluble COD (g/L) & $6.3 \pm 0.5$ & $0.7 \pm 0.01$ & $1.3 \pm 0.02$ \\
Volatile fatty acids (g/L) & $5 \pm 0.5$ & $0.07 \pm 0.002$ & $0.09 \pm 0.002$ \\
pH & $5.6 \pm 0.03$ & $7 \pm 0.04$ & $7.31 \pm 0.03 \mathrm{~s}$ \\
NH ${ }_{4}(\mathrm{~g} / \mathrm{L})$ & $0.27 \pm 0.02$ & $0.5 \pm 0.03$ & $0.6 \pm 0.03$ \\
Volatile solid (VS) removal & - & 47 & 52 \\
(\%) & & & \\
Degradable VS removal (\%) & - & 86 & 97 \\
Total COD removal (\%) & - & 48 & 56 \\
$\begin{array}{l}\text { Degradable COD removal } \\
\text { (\%) }\end{array}$ & - & 83 & 95 \\
COD balance (\%) & - & -3.9 & -4.5 \\
$\begin{array}{l}\text { Biogas (mL/g VS added) } \\
\text { Methane (mL/g VS added) }\end{array}$ & - & 683 & 747 \\
$\begin{array}{l}\text { Methane (mL/g VS } \\
\text { removed) }\end{array}$ & - & 450 & 513 \\
\hline
\end{tabular}

The influent $\mathrm{pH}$ and VFA values were well-matched with the individuals studied previously [14]. Operation 2 continued for 30 days that indicates four maintenance periods for both digesters. The methane generation of both digesters throughout operation 2 is presented in Fig. 2. After 11 days, the methane generation was enhanced in both digesters. After $16^{\text {th }}$ day methane generation turned into more consistent. The $\mathrm{pH}$ trained maintained nearly similar nature as the methane generation. At the end of $24^{\text {th }}$ days, the $\mathrm{pH}$ might have been around 7 to 7.31 in both digesters, respectively whereas the feed $\mathrm{pH}$ was seen to be 5.6. The digester output has been listed in Table-2. The thermophilic digester attained $52 \%$ volatile solid removal, contrasted with just $47 \%$ of that of mesophilic digester. The improved volatile solid and COD removal of thermophilic digester brought about a higher methane generation by over $13 \%$ than that of mesophilic digester. As the influent ammonia concentration of $279 \mathrm{mg} / \mathrm{L}$ was reduced higher protein degradation was obtained from thermophilic digester.

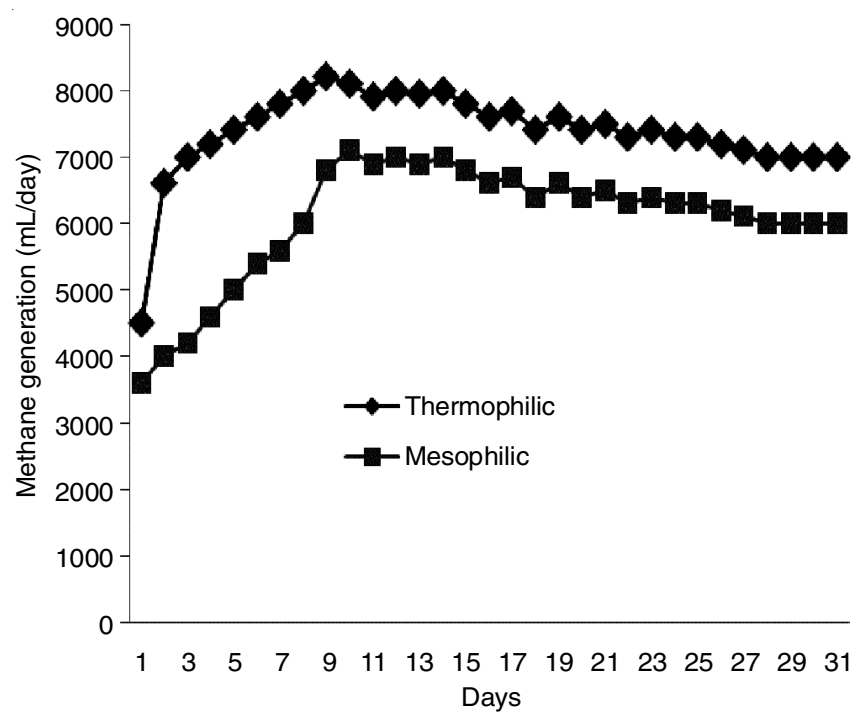

Fig. 2. Gas production during the semi-continuous digestion of MSS + CWAS + PWW (operation 2)
Corelation between operation 1, operation 2 and batch mesophilic co-digestion: The removal of degradable COD under mesophilic state for MSS, CWAS, PWW and MSS39+ CWAS61 is shown in Table-3. Simulation of the removal of the degradable COD, furthermore its change in to methane, from MSS, CWAS and PWW specimens in light of first-order kinetics produced rate constants as: MSS 0.21 per day; CWAS starting with 0.11 and ended with 0.04-0.06 per day and PWW from 0.11 to 0.16 per day. In addition, first-order kinetics rate constants for the MSS38 + CWAS62 were 0.16 per day initially and subsequently 0. 03-0.07 per day [10] likewise accounted that for a MSS32 + CWAS52 + PWW13 sample, those rate constants were: starting 0. 07-0.09 per day. It indicated that the supplementation of PWW made the digestion process faster in the carbonaceous environment.

\begin{tabular}{lccc}
\multicolumn{4}{c}{ TABLE-3 } \\
\multicolumn{1}{c}{ COMPARISON OF FRACTION OF COD REMOVED IN 13 DAYS } \\
\hline \multicolumn{1}{c}{ Parameters } & Influent & $\begin{array}{c}\text { Effluent } \\
\text { (Meso- } \\
\text { philic) }\end{array}$ & $\begin{array}{c}\text { Effluent } \\
\text { (Thermo- } \\
\text { philic) }\end{array}$ \\
\hline MSS $^{\mathrm{a}}$ & Batch & 0.84 & - \\
$\mathrm{CWAS}^{\mathrm{a}}$ & $\begin{array}{c}\text { Batch } \\
\text { BOG }\end{array}$ & 0.43 & - \\
MSS + CWAS (39/61 VS) $^{\mathrm{a}}$ & $\begin{array}{c}\text { Batch } \\
\text { MSS + CWAS (39/61 VS) }\end{array}$ & 0.74 & - \\
& $\begin{array}{c}\text { Semi- } \\
\text { continuous }\end{array}$ & 0.67 & - \\
MSS + CWAS + PWW & $\begin{array}{c}\text { Semi- } \\
(21 / 31 / 48 \text { VS) }\end{array}$ & 0.84 & 0.75 \\
\hline
\end{tabular}

MSS = Municipal sewage sludge, CWAS $=$ Condensed waste activated sludge, $\mathrm{PWW}=$ Petrochemical wastewater, FOG $=$ Fats, oil and grease

The fraction of degradable COD that might have been digested in operations 1 and 2 at mesophilic and thermophilic states is demonstrated in Table-3. Hypothetically, dependent upon first-order kinetics, batch co-digestion was 19-26\% more COD removal in Table-1 for 11-21 days continuous co-digestion [10]. The thermophilic states throughout operation 1 produced a higher fragmentary digestion of degradable COD that was over 0.73 .

A significant higher COD removal has been detected for operation 2 . The fragmentary degradable COD removal of 0.84 at mesophilic a state complies with that of MSS and surpasses that of CWAS and FOG in 13 days co-digestion. This improvement may be due to increased loading and bacteriological activity in the semi-continuous system and in addition of the impact of operation 2 acidification. Subsequent improvement of the fractional COD degradation at thermophilic state throughout operation 2 brought about the near-complete fragmentary degradable COD removal of 0. 96 .

Profit of PWW co-digestion: Volatile solid digestibility of PWW co-digestion with MSS (71 \%) might have been two times more over individual digestion of cattle manure (CM) and PWW [10]. The petrochemical wastewater (PWW) has a higher VS/TS ratio, 2 times more volatile solid based methane yield. These features showed that addition of PWW with digestion of MSS can remarkably increase the methane production. A theoretical and practical PWW-derived methane generation has been shown in Table-4. Based on the degradability criteria, PWW methane generation form $0.994 \mathrm{~m}^{3} / \mathrm{kg}$ VS added, estim- 


\begin{tabular}{|c|c|}
\hline $\begin{array}{c}\text { TABLE-4 } \\
\text { THEORETICAL AND PRACTICAL } \\
\text { PWW-DERIVED METHANE GENERATI }\end{array}$ & \\
\hline Parameters & Value \\
\hline PWW VS (kg/d) & 908 \\
\hline PWW VS (kg/d) & 876 \\
\hline $\begin{array}{l}\text { Ultimate methane yield from PWW (L @ STP/Kg) VS } \\
\text { added }^{\text {a }}\end{array}$ & 994 \\
\hline Assumed extent of ultimate methane yield (\%) & 84 \\
\hline Methane produced $\left(\mathrm{m}^{3} / \mathrm{year}\right)^{\mathrm{b}}$ & 289000 \\
\hline Value of produced methane (US dollars/year) ${ }^{c}$ & 122999 \\
\hline Methane value of PWW (US dollars $\left./ \mathrm{m}^{3}\right)^{\mathrm{d}}$ & 7 \\
\hline \multicolumn{2}{|c|}{$\begin{array}{l}{ }^{a} \text { Reported by Siddique and Wahid [10]; }{ }^{b} \text { At } 20 \mathrm{C} \text { and } 1 \mathrm{~atm} ;{ }^{\mathrm{c}} \mathrm{At} \$ \\
11.85 / \mathrm{GJ}\left(\$ 1.25 / \text { therm); }{ }^{\mathrm{d}} \text { At as received by haulers PWW }\right. \\
\text { concentration of } 2 \% \text { solids by weight. }\end{array}$} \\
\hline
\end{tabular}

ating that 84\% of methane generation will make US \$ 122999 per year in full scale anaerobic co-digestion.

\section{Conclusion}

Under semi-continuous feeding supplementation of petrochemical wastewater (PWW) portion (49\% of VS load) in an MSS + CWAS blend brought about 2.94 times higher methane yield, 153 versus $450 \mathrm{~mL}$ methane/g VS at mesophilic state and 2.59 times bigger methane yield, 198-513 L methane $/ \mathrm{kg}$ VS at thermophilic state. These effects demonstrate that those co-digestion of PWW with MSS could fundamentally increase methane generation. The enhancement in methane generation might be huge for MSS with generally low biodegradability (for instance for long SRT values) and for high PWW loading, as might have been those the event in this consider. In Malaysia, PWW is presently just something like $6 \%$ of the VS load and may be worth around $\$ 144,000 /$ year reduction in gas consumption, a worth that could be expanded to approximately threefold. However, economical and treatment system considerations should be studied as the effluent nutrients are more under $55^{\circ} \mathrm{C}$ than that of $37^{\circ} \mathrm{C}$.

\section{ACKNOWLEDGEMENTS}

The authors are thankful to School of Ocean Engineering, Universiti Malaysia Terengganu (UMT) and Faculty of Engineering Technology at the Universiti Malaysia Pahang (UMP) for allowing continuous access to their laboratory services. The present study was supported under grant No. UMP RDU 160315.

\section{CONFLICT OF INTEREST}

The authors declare that there is no conflict of interests regarding the publication of this article.

\section{REFERENCES}

1. X. Jia, D. Jin, C. Li and W. Lu, Chin. J. Chem. Eng., 27, 444 (2019); https://doi.org/10.1016/j.cjche.2018.04.030.

2. M.N.I. Siddique, M.S.A. Munaim and Z.B.A. Wahid, J. Clean. Prod., 145, 303 (2017);

https://doi.org/10.1016/j.jclepro.2017.01.061.

3. Y. Huang, M. Luo, Z. Xu, D. Zhang and L. Li, Sep. Purif. Technol., 211, 269 (2019); https://doi.org/10.1016/j.seppur.2018.09.080.

4. J.C. Kabouris, U. Tezel, S.G. Pavlostathis, M. Engelmann, J. Dulaney, R.A. Gillette and A.C. Todd, Bioresour. Technol., 100, 3701 (2009); https://doi.org/10.1016/j.biortech.2009.02.024.

5. M. Fountoulakis, I. Petousi and T. Manios, Waste Manag., 30, 1849 (2010); https://doi.org/10.1016/j.wasman.2010.04.011.

6. Å. Davidsson, C. Lövstedt, J. la Cour Jansen, C. Gruvberger and H. Aspegren, Waste Manag., 28, 986 (2008);

https://doi.org/10.1016/j.wasman.2007.03.024.

7. S. Luostarinen, S. Luste and M. Sillanpää, Bioresour. Technol., 100, 79 (2009); https://doi.org/10.1016/j.biortech.2008.06.029.

8. F.-M. Pellera and E. Gidarakos, Waste Manag., 68, 103 (2017); https://doi.org/10.1016/j.wasman.2017.06.026.

9. M.N.I. Siddique, M.S.A. Munaim and A.W. Zularisam, J. Taiwan Inst. Chem. Eng., 58, 451 (2016); https://doi.org/10.1016/j.jtice.2015.06.038.

10. M.N.I. Siddique and Z.A. Wahid, J. Clean. Prod., 194, 359 (2018); https://doi.org/10.1016/j.jclepro.2018.05.155.

11. M.N.I. Siddique, M. Sakinah Abd Munaim and A.W. Zularisam, J. Ind. Eng. Chem., 20, 331 (2014); https://doi.org/10.1016/j.jiec.2013.03.030.

12. N.I. Siddique, M.S.A. Munaim and Z.A. Wahid, J. Clean. Prod., 91, 229 (2015); https://doi.org/10.1016/j.jclepro.2014.12.036.

13. H. Liu, P. Han, H. Liu, G. Zhou, B. Fu and Z. Zheng, Bioresour. Technol., 260, 105 (2018); https://doi.org/10.1016/j.biortech.2018.03.105.

14. H. Guven, R.K. Dereli, H. Ozgun, M.E. Ersahin and I. Ozturk, Progr. Energy Combust. Sci., 70, 145 (2019); https://doi.org/10.1016/j.pecs.2018.10.002. 